\title{
TERT biology and function in cancer: beyond immortalisation
}

\author{
Ana Pestana1,2, João Vinagre',2, Manuel Sobrinho-Simões ${ }^{1,2,3,4,5}$ and Paula Soares \\ 1'Institute of Molecular Pathology and Immunology, University of Porto (IPATIMUP), Porto, Portugal \\ 2Institute for Research and Innovation in Health (I3S), University of Porto, Porto, Portugal \\ ${ }^{3}$ Medical Faculty, University of Porto, Porto, Portugal \\ ${ }^{4}$ Department of Pathology, Centro Hospitalar S. João, Porto, Portugal \\ ${ }^{5}$ Department of Pathology, Medical Faculty, University of Porto, Porto, Portugal
}

Correspondence

should be addressed

to $P$ Soares

Email

psoares@ipatimup.pt

\begin{abstract}
Evasion of replicative senescence and proliferation without restriction, sometimes designated as immortalisation, is one of the hallmarks of cancer that may be attained through reactivation of telomerase in somatic cells. In contrast to most normal cells in which there is lack of telomerase activity, upregulation of TERT transcription/activity is detected in $\mathbf{8 0 - 9 0 \% ~ o f ~ m a l i g n a n t ~ t u m o u r s . ~ I n ~ s e v e r a l ~ t y p e s ~ o f ~ c a n c e r , ~ t h e r e ~ i s ~ a ~}$ relationship between the presence of TERT promoter mutations, TERT mRNA expression and clinicopathological features, but the biological bridge between the occurrence of TERT promoter mutations and the aggressive/invasive features displayed by the tumours remains unidentified. We and others have associated the presence of TERT promoter mutations with metastisation/survival in several types of cancer. In follicular cell-derived thyroid cancer, such mutations are associated with worse prognostic features (age of patients, tumour size and tumour stage) as well as with distant metastases, worse response to treatment and poorer survival. In this review, we analyse the data reported in several studies that imply TERT transcription reactivation/activity with cell proliferation, tumour invasion and metastisation. A particular attention is given to the putative connections between TERT transcriptional reactivation and signalling pathways frequently altered in cancer, such as c-MYC, NF-кB and B-Catenin.
\end{abstract}

Journal of Molecular Endocrinology (2017) 58, R129-R146

\section{Introduction}

In 1965, Hayflick described that human cells in culture had a finite lifetime in vitro, being able to divide 40-60 times before they would reach a gradual cessation of mitotic activity, a state now known as replicative senescence, and this limit was coined Hayflick limit (Hayflick 1965). In 1973, Olovnikov proposed that due to semi-conservative DNA replication, linear DNA of eukaryotic chromosomes would shorten with each round of DNA replication (Olovnikov 1973). Later, it was described that telomeres shortened 50-200 bp at each round of division, until a critical limit was achieved and replicative senescence was reached (Szostak \& Blackburn 1982, Blackburn 1991, Greider 1991).

Telomeres are cellular nucleoprotein complexes whose main function is to maintain chromosomal integrity and genome stability (Blackburn 2001). Telomeres are formed by hexameric repeats of a 5'-TTAGGG-3' sequence ending in a 3' single-stranded overhang, the G-strand overhang (Moyzis et al. 1988, Makarov et al. 1997, Wellinger \& Sen 1997) that protects the genomic DNA from the continued erosion of telomeres during cell division.

Telomerase is a ribonucleoprotein polymerase with reverse transcriptase activity, capable of reversing the

Published by Bioscientifica Ltd 
continued erosion of telomeres by adding 5'-TTAGGG-3' tandem repeats at the end of the chromosomes (Liu et al. 2004). In somatic cells, telomerase remains inactive, but its activity can be found in germ cells and in stem cells in self-renewing tissues (Liu et al. 2004).

Human telomerase is composed of two main core subunits: telomerase reverse transcriptase (TERT) that constitutes the catalytic subunit and a RNA component (TERC) that provides a template for telomerase elongation (Greider \& Blackburn 1989, Lendvay et al. 1996, Lingner $\&$ Cech 1996). The telomerase complex comprises several other molecules (Liu et al. 2004); of all its components, TERT and TERC are essential for the reconstitution of telomerase activity (Ishikawa 1997, Weinrich et al. 1997, Beattie et al. 1998). TERC is widely expressed in most cell types and even in telomerase-negative cells (Meyerson et al. 1997, Nakamura et al. 1997), whereas TERT expression is highly regulated, being absent or only present in low levels in somatic cells (Cong et al. 1999, Yi et al. 1999, Li et al. 2003). Lymphocytes are the only group of somatic cells that present telomerase activity and TERT expression. This activity is highly regulated during development, differentiation and activation of both $\mathrm{T}$ and B lymphocytes (Broccoli et al. 1995, Chiu et al. 1996, Morrison et al. 1996, Weng et al. 1998).

A positive correlation between TERT mRNA expression and telomerase activity has been observed, thus suggesting that telomerase is primarily regulated by TERT gene expression (Cong et al. 1999, Yi et al. 1999, Li et al. 2003).

Human TERT gene is located on chromosome 5p15.33 (Cong et al. 1999, Bryce et al. 2000), spanning 16 exons and $40 \mathrm{~kb}$ (Cukusic et al. 2008). The TERT promoter region is considered the most important regulatory element for telomerase expression (Cukusic et al. 2008). It spans $330 \mathrm{bp}$ upstream of the translational start site and $37 \mathrm{bp}$ of exon 2 (Cong et al. 1999, Cukusic et al. 2008), where the $181 \mathrm{bp}$ fragment upstream of the transcriptional start site is the core functional promoter essential for transcriptional activation of TERT in cancer cells (Takakura et al. 1999). The promoter region is rich in CpG dinucleotides and SP1 sites, lacking both TATA and CAAT boxes (Takakura et al. 1999). This $5^{\prime}$ regulatory region is known to be enriched with transcriptional-binding sites/consensus that interact with both negative and positive regulators of TERT (Renaud et al. 2005, Cukusic et al. 2008), indicating a high level of regulation by multiple factors (Cong et al. 1999) at transcriptional level (Cifuentes-Rojas \& Shippen 2012).

One of the hallmarks of cancer is the evasion of replicative senescence and proliferation without restriction, designated as immortalisation, and one of the ways to attain this hallmark is through reactivation of telomerase in somatic cells (Liu et al. 2004). Telomerase activity has been consistently detected in 80-90\% of malignant tumours (Kim et al. 1994, Shay \& Bacchetti 1997).

In cancer cells, in contrast to most normal cells, upregulation of TERT transcriptional activity has been described (Wright et al. 1996, Takakura et al. 1999). Differential upregulation of TERT activity has been described in cancer cells due to several processes, including transcriptional regulation, alternate RNA splicing and post-translational modifications such as protein phosphorylation (Cong et al. 2002, Cukusic et al. 2008).

In 2013, two groups reported the presence of mutations in the TERT promoter in melanoma (Horn et al. 2013, Huang et al. 2013). Shortly after, several groups reported the presence of recurrent somatic mutations in other types of cancer, namely in central nervous system, bladder, liver, thyroid, skin and others (Killela et al. 2013, Liu et al. 2013a, Nault et al. 2013, Scott et al. 2013, Vinagre et al. 2013, Allory et al. 2014, Hurst et al. 2014, Wu et al. 2014).

The TERT promoter mutations, commonly detected in the $-124(\mathrm{C} 228 \mathrm{~T})$ and $-146 \quad(\mathrm{C} 250 \mathrm{~T})$ residues (C>T or G > A in the reverse strand) (Horn et al. 2013, Huang et al. 2013), create an 11-base nucleotide stretch 5'-CCCCTTCCGGGG-3', which contains a consensus binding site, GGAA (in reverse complement), for E-twenty six (ETS) family of transcription factors, providing a basis to the biological relevance of these mutations (Horn et al. 2013, Huang et al. 2013). Most ETS factors are ubiquitously expressed in normal human tissues and may be found to be overexpressed in tumours or cancer cell lines (Oikawa \& Yamada 2003).

These recently described mutations represent one of the possible explanations for telomerase reactivation and activity in cancer cells, which can ultimately lead to cell immortalisation.

\section{TERT promoter mutations in thyroid cancer}

Thyroid cancer is the most common endocrine neoplasia (Hegedus 2004), whose incidence has been increasing, $6 \%$ per year, worldwide over the last few decades (La Vecchia et al. 2015). The thyroid tissue is a conditional renewal tissue, displaying a very low proliferative rate. Human thyroid cells are believed to divide up to five times in the adult life (Dumont et al. 1991). In the thyroid gland, there is no well-defined stem cell population that

Published by Bioscientifica Ltd. 
might constitute a pool of cells responsible for retaining the capacity of tissue renewal. Some authors described so-called solid cell nests (SCNs) of the thyroid, which are embryonic remnants of the ultimobranchial body: these may represent the thyroid stem cell pool, as they express several stem cell markers, namely telomerase (Reis-Filho et al. 2003, Preto et al. 2004).

Thyroid cancer displays less frequent telomerase activation than other cancer types; telomerase activity has been found in $48 \%$ of papillary thyroid carcinomas (PTC), $71 \%$ of follicular thyroid carcinomas (FTC) and 78\% of poorly differentiated and anaplastic thyroid carcinomas (PDTC and ATC, respectively) (Aogi et al. 1999, Saji et al. 1999, Hoang-Vu et al. 2002, Takano et al. 2007).

Recent studies have demonstrated that, so far, TERT promoter mutations were only detected in thyroid follicular cell-derived cancer, such as differentiated thyroid carcinoma (DTC), which includes the PTC and FTC and in PDTC and ATC. These mutations were virtually absent in sporadic benign lesions such as goitre, adenoma or thyroiditis (Landa et al. 2013, Liu et al. 2013a,b, Vinagre et al. 2013, Wang et al. 2014). TERT promoter mutations were found in 5-26\% of the PTC (Landa et al. 2013, Liu et al. 2013a,b, 2014, Vinagre et al. 2013, Liu \& Xing 2014, Melo et al. 2014, Xing et al. 2014, Muzza et al. 2015, Qasem et al. 2015, Crescenzi et al. 2016), 0-36 \% of the FTC (Liu et al. 2013a,b, 2014, Vinagre et al. 2013, Liu \& Xing 2014, Melo et al. 2014, Muzza et al. 2015, Qasem et al. 2015, Crescenzi et al. 2016), 21-52\% of PDTC (Landa et al. 2013, 2016, Liu et al. 2013b, Vinagre et al. 2013, Melo et al. 2014, Qasem et al. 2015) and in 13-50\% of ATC (Landa et al. 2013, 2016, Liu et al. 2013b, Vinagre et al. 2013, Melo et al. 2014).

We and others have associated the presence of TERT promoter mutations with metastisation/survival in several types of cancer, namely in melanoma (Populo et al. 2014), gliomas (Heidenreich et al. 2015) and thyroid carcinomas (Melo et al. 2014). Specifically, in thyroid cancer, our group and others reported that these mutations are associated with worse prognostic features (age of patients, tumour size and tumour stage), as well as with distant metastases, worse response to treatment and poor survival (Landa et al. 2013, Liu \& Xing 2014, Liu et al. 2013a,b, Melo et al. 2014, George et al. 2015, Qasem et al. 2015, Nasirden et al. 2016). TERT promoter mutations were also associated with shorter survival and/or short disease-free survival in melanomas (Griewank et al. 2014, Populo et al. 2014, Nagore et al. 2016) and glioblastomas (Mosrati et al. 2015, Simon et al. 2015, Batista et al. 2016, Yuan et al. 2016).
In a large cohort of patients with metastatic thyroid carcinoma, TERT promoter mutations were more frequently detected in radioiodine-refractory distant metastasis than in lymph node metastasis or primary tumours (Melo M, da Rocha AG, Batista R, Vinagre J, Martins MJ, Costa G, Ribeiro C, Carrilho F, Leite V, Lobo C, Cameselle-Teijeiro JM, Cavadas B, Pereira L, Sobrinho-Simões $\mathrm{M} \&$ \& Soares $\mathrm{P}$, unpublished observations). These results suggest that TERT promoter mutations appear to have a role in distant metastisation in thyroid carcinomas (Melo M, da Rocha AG, Batista R, Vinagre J, Martins MJ, Costa G, Ribeiro C, Carrilho F, Leite V, Lobo C, Cameselle-Teijeiro JM, Cavadas B, Pereira L, Sobrinho-Simões M \& Soares P, unpublished observations). Landa and coworkers recently reported that TERT promoter mutations were subclonal in the few PTCs that harbour them, whereas they are clonal and highly prevalent in the more aggressive forms of the disease, PDTCs and ATCs, which suggest clone selection during tumour evolution (Landa et al. 2016).

In a Tinea capitis radiation context, TERT promoter mutations were detected in $12 \%$ of carcinomas and in $21 \%$ of adenomas, being the most frequent, the $-146 \mathrm{C}>\mathrm{T}$ and the tandem mutations (Boaventura et al. 2016). These results point that TERT promoter mutations in this background present a different mutational signature (higher frequency of the $-146 \mathrm{C}>\mathrm{T}$ ), and although it may be an early genetic event, they do not seem pivotal to the carcinogenic process in this setting; it has been demonstrated that the $-146 \mathrm{C}>\mathrm{T}$ confers a decreased transcriptional activity capacity when compared to the $-124 \mathrm{C}>\mathrm{T}$ mutation (Rachakonda et al. 2013). This event does not appear to drive carcinogenesis, at least per se, as TERT promoter mutations are not more prevalent in the carcinomas arising in irradiated setting than those in the sporadic well-differentiated carcinomas (Boaventura et al. 2016).

Several associations between the co-occurrence of TERT promoter mutations and other genetic alterations, such as BRAF and RAS mutations, have been reported in the literature. In melanoma, TERT promoter mutations are the most frequent somatic alteration and consistently co-occur with BRAF/RAS mutations (Horn et al. 2013, Griewank et al. 2014, Heidenreich et al. 2014, Populo et al. 2014, Macerola et al. 2015, Landa et al. 2016). In thyroid carcinomas, a positive association between co-occurrence of TERT promoter and BRAF mutations and a trend for co-occurrence with $R A S$ mutations in primary tumours have been described (Landa et al. 2013, Liu et al. 2013a,b, 2014,

Published by Bioscientifica Ltd. 
Vinagre et al. 2013, Xing et al. 2014, Muzza et al. 2015, Crescenzi et al. 2016).

One of the possibilities to explain the synergy between the co-occurrence between TERT promoter and BRAF/RAS mutations is the activation of the MAPK and/or PI3-Akt pathways that will culminate in the increased expression of ETS transcriptional factors, that can bind to the novel binding consensus sites created by the mutations and in this way upregulate TERT expression (Horn et al. 2013, Huang et al. 2013). Several studies reported evidence that confirm this possibility for cooperation between TERT promoter and BRAF/RAS mutations. Vallarelli and coworkers (Vallarelli et al. 2016) described that in melanoma, TERT promoter mutations provided a direct link between TERT expression and MAPK pathway activation due to BRAF or NRAS mutations via the transcription factor ETS1, that would bind to the mutated promoter leading to the re-expression of TERT. Also, in non-small-cell lung cancers (NSCLC), Liu and coworkers described that KRAS mutations increased TERT mRNA expression and telomerase activity by activating the RAS/MEK pathway, which contributes to the aggressive phenotype of NSCLC (Liu et al. 2016b).

Even though there is a positive association between the co-occurrence of TERT promoter and BRAF/RAS mutations, there is not a consensus in the literature about the combined prognostic value of these events. Some groups report that co-occurrence of TERT promoter and BRAF mutations are associated with worse prognosis factors in thyroid cancer (Allory et al. 2014, Liu et al. 2014, 2016a, Xing et al. 2014, Song et al. 2016), whereas other authors have not found this association in other series (Melo et al. 2014, 2015, George et al. 2015, Nasirden et al. 2016).

Although associations have been established in several cancers between the occurrence of TERT promoter mutations, TERT mRNA expression levels and clinicopathological features, the biological bridge between the presence of TERT promoter mutations and the aggressive/invasive features displayed by the tumours remains unidentified. There are two possible scenarios, not mutually exclusive, that may explain this finding. The first is that with the immortalisation, TERT promoter-mutated cells become more resistant to cell death during invasion, circulation and homing steps and are therefore more successful in the establishment of metastases. The second one is that TERT promoter mutations can give metastatic advantages to the cells by modulating/regulating (through TERT-regulated transcription programs) proteins and/or pathways important for the metastatic process (motility, invasion and MMPs).

\section{Regulators and targets of TERT within major signalling pathways altered in cancer}

In cancer cells TERT is transcriptionally reactivated; several signalling pathways have been implicated in this process, namely c-MYC (Greenberg et al. 1999), nuclear factor k-light-chain-enhancer of activated B cells (NF-kB) (Yin et al. 2000) and B-Catenin (Zhang et al. 2012). The main interactions of TERT with these signalling pathways are summarised in Table 1.

c-MYC has been described as a regulator of TERT transcription program, and this hypothesis was suggested in 1999, when Greenberg and coworkers described TERT gene as a direct transcriptional target of c-MYC. c-MYC binds to the E-box (5'-CACGTG-3') in the TERT promoter region and activates TERT promoter (Greenberg et al. 1999).

c-MYC is able to induce telomerase activity through direct control of TERT transcription as this region has several binding sites/consensus for c-MYC (Wu et al. 1999). Both in normal human mammary epithelial cells (HMECs) and normal human diploid fibroblasts, the increased telomerase activity leads to extension of cell life span and proliferation (Wu et al. 1999). In a model of vascular injury, TERT was de novo activated in the intima of the injured arteries, involving activation of NF- $\mathrm{KB}$ (Bu et al. 2010). Isolated intimal smooth muscle cell (SMC) stimulation with basic fibroblast growth factor or tumour necrosis factor alpha (TNF alpha) led to increased TERT activity; this effect was dependent on c-MYC activation as abrogation of c-MYC expression, by mutation of c-MYC-binding site or by c-MYC competitor, abrogated the transcriptional activity (Bu et al. 2010). Inhibition of NF- $\mathrm{kB}$ also attenuated TERT transcriptional activity by the reduction of c-MYC expression (Bu et al. 2010).

It seems that TERT also regulates c-MYC stability in cancer. TERT is responsible for stabilisation of c-MYC levels in chromatin, contributing to either activation or repression of its target genes. TERT regulates c-MYC ubiquitination and proteosomal degradation, independent of its telomeric role, suggesting a feedforward mechanism able to potentiate c-MYC-dependent oncogenesis (Koh et al. 2015).

$\mathrm{NF}-\kappa \mathrm{B}$ is one of the most mentioned pathways altered in cancer that controls TERT transcriptional program. In 2000, the existence of a NF-kB-binding site in the TERT promoter, specific for p50 and p65 was described (Yin et al. 2000). The fusion with a basal SV40 promoter activates transcription and enhances the activity of the native TERT promoter in mouse hepatoma cells when treated with a NF-kB stimulator (Yin et al. 2000).

Published by Bioscientifica Ltd. 
Table 1 Summary of multiple interactions of TERT with major signalling pathways, namely c-MYC, NF-kB and Wnt/B-Catenin pathways.

\begin{tabular}{|c|c|}
\hline TERT & Interaction effects \\
\hline c-MYC & $\begin{array}{l}\text { Induction of TERT } \\
\text { transcriptional activity } \\
\text { Induction of telomerase } \\
\text { activity }\end{array}$ \\
\hline
\end{tabular}

NF-KB

Wnt/B-Catenin
Induction of TERT transcription activity

Induction of telomerase activity

Repression of ROS-dependent activation

Modulation of TERT nuclear

translocation

Recruitment of IL6 and TNF

alpha

Upregulation of MMPs 1, 3, 9

and 10

Induction of TERT transcription activity

Induction of telomerase

activity

Activation of Wnt-depend

reporters
In MM.1S cells, NF-kB appears to have an important role in regulating telomerase activity by modulating nuclear translocation of TERT protein bound to NF- $\mathrm{kB}$, in response to TNF alpha stimulation (Akiyama et al. 2003). Also, in response to TNF alpha, it seems that human telomerase represses reactive oxygen species (ROS)dependent intracellular signalling and gene induction (Mattiussi et al. 2012). In HepG2 cells, NF-кB appears to modulate TERT mRNA levels in a dose-dependent manner by stimulation of NF-kB pathway (p65) (Zuo et al. 2011). A feed-forward regulation between TERT and NF-кB was suggested as telomerase directly regulates NF-кBdependent gene expression by binding to the NF-кB p65 subunit (Ghosh et al. 2012). This leads to the recruitment of a subset of NF-kB promoters such as Interleukin 6 (IL6) and TNF alpha. These cytokines, which are critical for inflammation and cancer progression, together with $\mathrm{NF}-\kappa \mathrm{B}$, can transcriptionally upregulate telomerase levels (Ghosh et al. 2012).

\begin{tabular}{l}
\hline Cell effects \\
\hline Extension of cell life span \\
Cell proliferation \\
Replicative longevity of \\
vascular cells \\
Activation or repression of its \\
target genes \\
Potentiation of c-MYc- \\
dependent oncogenesis \\
Extension of cell life span \\
Cell proliferation \\
Replicative longevity of \\
vascular cells \\
Activation or repression of its \\
target genes \\
Potentiation of c-MYC \\
dependent oncogenesis \\
Repression of ROS-dependent \\
intracellular signalling and \\
gene induction \\
Inflammation \\
Cancer progression \\
Invasion
\end{tabular}

References

(Wu et al. 1999)

(Bu et al. 2010)

(Koh et al. 2015)

(Yin et al. 2000)

(Zuo et al. 2011)

(Mattiussi et al. 2012)

(Akiyama et al. 2003)

(Ghosh et al. 2012)

(Ding et al. 2013)

(Zhang et al. 2012)

(Park et al. 2009)
It was described that telomerase activity was not only related to transcriptional regulation of TERT by NF-kB but also by post-transcriptional regulation by phosphorylation of TERT by Akt kinase (Akiyama et al. 2002). In multiple myeloma cells, IL6 and insulin-like growth factor 1 (IGF1) would upregulate telomerase activity without alteration of TERT protein expression, and this increase was due to the PI3K/Akt/NF-кB signalling (Akiyama et al. 2002).

Another pathway involved in the regulation of TERT is the Wnt/B-Catenin. It was described that TERT interacts with BRG1, a SWI/SNF-related chromatin remodelling protein, and activates Wnt-dependent reporters in cultured cells and in vivo, where TERT physically occupies gene promoters of Wnt-dependent genes (Park et al. 2009). Transient activation of Wnt/B-Catenin induced TERT mRNA expression and elevated telomerase activity in different cell lines. This activation was dependent on TCF4, as TERT is a direct target of B-Catenin TCF4mediated transcription. TCF4-binding site at the TERT

Published by Bioscientifica Ltd. 
promoter is critical for B-Catenin TCF4-dependent expression regulation (Zhang et al. 2012). B-Catenin also regulates TERT expression through the interaction with Klf4, a core component of the pluripotency transcriptional network in a mouse intestinal tumour model and in human carcinoma cells (Hoffmeyer et al. 2012).

Human and mouse HIV-associated nephropathy (HIVAN) show increased levels of TERT and activation of Wnt signalling (Shkreli et al. 2012). Either silencing TERT expression or inhibition of Wnt signalling, through systemic expression of the Wnt inhibitor Dkk1, in TERT transgenic mice results in a marked normalisation of podocytes, rapid cell cycle exit, re-expression of differentiation markers and improved filtration barrier function (Shkreli et al. 2012).

In contrast to the previously described results, one study failed to find evidence for physical association of TERT with BRG1 or B-Catenin in human breast cancer lines and HeLa cells (Listerman et al. 2014). Instead, these authors suggest that anti-FLAG antibody cross-reactivity properties may explain the previously reported interaction of TERT with B-Catenin (Park et al. 2009). Furthermore, altering TERT levels in four different breast cancer cell lines caused minimal and discordant effects on Wnt target and Wnt pathway gene expression (Listerman et al. 2014).

Another study described that illegitimate activation of B-Catenin signalling enhances the transformation from immortalisation to malignant growth in human foetal hepatocytes (Wege et al. 2011). In this model, telomerase inhibition showed that short-term expansion of transformed clones was not telomerase dependent (Wege et al. 2011).

In mice mTERT+/- and mTERT-/- on the CAST/ EiJ genetic background, TERT overexpression in some settings may activate the Wnt pathways (Strong et al. 2011). However, loss of function in a physiological setting has no apparent effects on Wnt signalling (Strong et al. 2011). This deficiency leads to telomere shortening, that limits tissue renewal, and these effects are not telomereindependent functions of TERT (Strong et al. 2011).

\section{Interaction of TERT with other signalling pathways and cellular processes}

Besides the major TERT regulators and targets previously described, several roles for TERT have been described in other signalling pathways and cellular processes. Endoplasmic reticulum (ER) stress transiently activates TERT expression in human cancer cell lines and murine primary neural cells. Importantly, depletion of TERT sensitises cells to undergo apoptosis under ER stress, whereas increased TERT expression reduces ER stressinduced cell death independent of catalytically active enzyme or DNA damage signalling (Zhou et al. 2014). TERT exerts its anti-apoptotic action at an early stage of cell death process prior to mitochondrial dysfunction and caspase activation (Fu et al. 2000). TERT may serve as a neuron survival promoter in the developing brain, and downregulation of TERT in the adult brain may contribute to increased neuronal vulnerability in various age-related neurodegenerative disorders (Fu et al. 2000).

TERT can be targeted to the mitochondria by an N-terminal leader sequence, and mitochondrial extracts from seven different human cell lines show telomerase activity (Santos et al. 2004). The cellular effects of mitochondrial telomerase are controversial. Some authors argue that mitochondrial telomerase increases hydrogen peroxide $\left(\mathrm{H}_{2} \mathrm{O}_{2}\right)$-mediated mitochondrial DNA (mtDNA) damage. Ectopic TERT expression in human cells correlates with increase in mtDNA damage after $\mathrm{H}_{2} \mathrm{O}_{2}$ treatment (Santos et al. 2004). The same group later demonstrated that this increase in mtDNA damage after $\mathrm{H}_{2} \mathrm{O}_{2}$ exposure is dependent on the presence of TERT itself (Santos et al. 2006). Further experiments using a dominant negative TERT mutant show that telomerase must be catalytically active to mediate the increase in mtDNA damage. Mutations in the N-terminal mitochondrial leader sequence of TERT cause a complete loss of mitochondrial targeting without affecting catalytic activity. Cells carrying this mutated TERT not only have significantly reduced levels of mtDNA damage after $\mathrm{H}_{2} \mathrm{O}_{2}$ treatment, but strikingly also do not show any loss of viability or cell growth. Thus, the authors proposed that localisation of TERT to the mitochondria renders cells more susceptible to oxidative stress-induced mtDNA damage and subsequent cell death. Nuclear targeted TERT, in the absence of mitochondrial localisation, is associated with diminished mtDNA damage, increased cell survival and protection against cellular senescence (Santos et al. 2006).

By contrast, several reports proposed that TERT mitochondrial localisation has a protective role against mtDNA damage. Ahmed and coworkers (Ahmed et al. 2008) described that in a mild oxidative stress background, telomerase did not prevent telomere shortening under hyperoxia as it translocated gradually from the nucleus to mitochondria. TERT mitochondrial localisation reduced mtDNA damage levels under oxidative stress and improved mitochondrial function, with lower levels

Published by Bioscientifica Ltd 
of ROS and with enhanced mitochondrial membrane potential (Ahmed et al. 2008). Haendeler and coworkers (Haendeler et al. 2009) also reported TERT's protective role in mitochondria in an oxidative stress background. TERT binds to ND1 and ND2 genes, protecting against mtDNA damage, reducing mitochondrial ROS, and increasing energy metabolism and conferring higher protection from apoptosis (Haendeler et al. 2009).

Singhapol and coworkers (Singhapol et al. 2013) also described a correlation between TERT retained within the nucleus and high nuclear DNA damage. The group described a heterogeneous stress response in the exclusion of telomerase from the nucleus in cancer cell populations upon stress application. Cells that excluded telomerase quickly from the nucleus accumulated no or very low amounts of DNA damage, suggesting that mitochondrial telomerase prevents nuclear DNA damage as well as the induction of apoptosis after treatment with $\mathrm{H}_{2} \mathrm{O}_{2}$ and irradiation (Singhapol et al. 2013).

Recently, Muzza and coworkers (Muzza et al. 2016) described that in thyroid cancer, namely in PTC, there were no differences in mitochondrial oxidative stress between PTC and normal tissues, supporting the postulated role of mitochondrial TERT in the control of local $\mathrm{H}_{2} \mathrm{O}_{2}$ production. Although TERT nuclear expression did not differ between PTC and normal tissues, the mitochondrial expression of TERT was significantly higher in tumours. The authors suggest that in thyroid cancer, the elevated levels of ROS could be responsible for the shuttling of TERT from the nucleus to the mitochondria (Muzza et al. 2016).

A possible explanation for the opposing results concerning the role of mitochondrial telomerase was given by Gordon and Santos (Gordon \& Santos 2010) in their 2010 review on the subject. The authors suggest that controversial results may reflect differences in the cellular backgrounds, antioxidant defences and/or in the dose/ length of the stress (Gordon \& Santos 2010).

Additionally, TERT has been described to have influence in several other molecules and pathways, which modify responses to inflammation, cell death, apoptosis and DNA damage responses. For instance, in a comparison between normal and TERT immortalised fibroblasts using a cDNA microarray, Lindvall and coworkers (Lindvall et al. 2003) verified that TERT immortalised cells had 172 differentially expressed genes; one of them is epiregulin, a potent growth factor associated with cancer. The results suggest that both activation of telomerase and subsequent induction of epiregulin are required for a sustained cell proliferation (Lindvall et al. 2003).
Young and coworkers suggested two epigenetics mechanisms for the maintenance of a young phenotype in normal human fibroblasts with TERT re-expression. The first was the freezing of the epigenomic state of young proliferating cells by the stabilisation of DNA methylation; the second, the maintenance of low levels of the cell cycle inhibitor p21, mediated at least partially by DNMT1's transcriptional repressor activity (Young et al. 2003).

In human cervical cancer cell lines, p27/kip1, a tumour suppressor protein, can inhibit TERT mRNA expression and telomerase activity through post-transcriptional upregulation by interferon-c (IFNc)/IRF1 signalling. This suggests that p27 may have the function of tumour suppressor by inhibiting TERT expression (Lee et al. 2005). It was also described that TERT overexpression upregulated the expression and transcriptional activity of a key cell cycle regulator, cyclin D1, in human prostate epithelial cell lines. This means that TERT could have a role in the modulation of cyclin D1 expression (Jagadeesh \& Banerjee 2006). TERT is capable of activating the transcription of vascular endothelial growth factor (VEGF) in WI-38 and HeLa cells, this activation being independent of telomerase activity and telomere maintenance (Zhou et al. 2009).

Suppression of TERT expression abrogates the cellular response to DNA double-strand breaks. Loss of TERT does not alter short-term telomere integrity but instead affects the overall configuration of chromatin. Cells lacking TERT exhibit increased radiosensitivity, diminished capacity for DNA repair, fragmented chromosomes, demonstrating that loss of TERT impairs the DNA damage response (Masutomi et al. 2005).

\section{Role of TERT in proliferation, invasion and tumourigenesis}

The first evidence that TERT by itself was directly involved in tumourigenesis was reported in 2002 (Artandi et al. 2002). Transgenic mice expressing TERT at high levels had increased telomerase enzymatic activity in several tissues, such as mammary gland, splenocytes and cultured mouse embryonic fibroblasts. This was associated with spontaneous development of mammary intraepithelial neoplasia and invasive mammary carcinomas in a significant proportion of elderly females. This suggested that TERT expression could promote the development of spontaneous cancer even in the setting of ample telomere reserve (Artandi et al. 2002). In another experiment, using GM847 cell line that presents alternative lengthening of telomeres (ALT) phenotype, the authors showed that expression of oncogenic RAS failed to fully transform the

Published by Bioscientifica Ltd. 
cells. Nonetheless, with ectopic expression of TERT, the cells acquired a tumourigenic phenotype, suggesting that TERT had an additional function required for cellular transformation and not depending on its ability to maintain telomeres (Stewart et al. 2002). Following this line of reasoning, several studies confirmed the capacity of TERT to cooperate with other factors to promote tumourigenesis, for instance, when reduced viability and increased cancer incidence was noted in K5-TERT mice with a p53 (+/-) genetic background, indicating that telomerase could cooperate with loss of p53 function in inducing tumourigenesis in ageing organisms (GonzalezSuarez et al. 2002).

Okamoto and coworkers identified TERT as a necessary component to maintain a stem cell state of the tumour-initiating cells (TIC) (Okamoto et al. 2011). The formation of a complex TERT-GNL3L/NS, which are proposed as markers for TICs in highly aggressive tumours, seems to contribute directly to cancer stem cell formation (Okamoto et al. 2011).

With the use of a panel of TERT mutants transduced into HMECs, it was shown that TERT had at least four biological actions that were genetically separable and functionally independent (Mukherjee et al. 2011). TERT could enhance independently cell proliferation, telomere elongation, cellular lifespan extension and regulate DNA damage responses (Mukherjee et al. 2011).

Using telomerase overexpressing transgenic mice, Gonzalez-Suarez and coworkers showed that the epidermis of the mice was highly responsive to the mitogenic effects of phorbol esters (Gonzalez-Suarez et al. 2001). These mice were also more susceptible than the wild-type mice for the development of skin tumours upon chemical carcinogenesis induction (Gonzalez-Suarez et al. 2001). Curiously, telomerase transgenic mice showed an increased wound healing rate than wild-type mice (Gonzalez-Suarez et al. 2001).

Ectopic expression of telomerase in HMECs leads to an increased ability to proliferate. This expression results in a diminished requirement for exogenous mitogens and correlates with telomerase-dependent induction of genes that promote cell growth. Inhibition of one of these genes, for instance of the epidermal growth factor receptor (EGFR), reverses the enhanced proliferation caused by telomerase (Smith et al. 2003).

Several other studies implied the role of TERT in the enhancement of proliferation, in mouse skin epithelium, specifically in the hair follicle bulge region (Sarin et al. 2005), keratinocyte proliferation in skin and activation of hair follicles stem cells (Flores et al. 2005).
Interestingly, several splicing variants of TERT were described in human and in chicken (Kilian et al. 1997, Wick et al. 1999, Hisatomi et al. 2003, Chang \& Delany 2006, Saeboe-Larssen et al. 2006, Amor et al. 2010). In 2012, another human variant was described, containing an in-frame deletion, which removed exons 4 through $13(\Delta 4-13)$, encoding the catalytic domain of telomerase (Hrdlickova et al. 2012). This variant was expressed in telomerase-negative normal cells and tissues, as well as in telomerase-positive cell lines (Hrdlickova et al. 2012). Its overexpression leads to elevated proliferation rates of several cell types, without affecting telomerase activity, by stimulation of Wnt signalling (Hrdlickova et al. 2012). Another study of splice variants described that the variant termed alpha+beta- or beta-deletion is highly expressed in stem and cancer cells (lacking most of the reverse transcriptase domain) and confers a growth advantage to breast cancer cells independent of telomere maintenance, by inhibiting cisplatin-induced apoptosis (Listerman et al. 2013).

In a mouse model with constitutive expression of TERT targeted to thymocytes and peripheral $\mathrm{T}$ cells, TERT was associated not only with the development of spontaneous $\mathrm{T}$ cell lymphoma but also to its dissemination (Canela et al. 2004). The T cell lymphomas in these mice were more disseminated than those in the age-matched wild type, affecting both lymphoid and non-lymphoid tissues, whereas the controls had only the lymphoid tissues affected. These results support the idea that TERT has a role in the promotion of tumour progression and dissemination independent of the role in telomere length maintenance (Canela et al. 2004).

In gastric cancer, TERT was implicated in metastisation in several studies: (i) TERT-overexpressing cells had higher levels of Mac2-binding protein (Mac2BP) (Park et al. 2007), a tumour antigen implicated in metastasis; (ii) TERT binds to c-MYC and recruits the complex to heparanase promoter to upregulate heparanase expression promoting invasion and metastasis of gastric cancer cells; furthermore, TERT-activated Wnt/B-Catenin signalling promotes c-MYC expression, which could in turn activate TERT transcription and expression in a positive feedback loop (Tang et al. 2016); (iii) finally, it has been shown that TERT regulation of ITGB1 in the MDM2-FOXO3aITGB pathway is able to promote gastric cancer invasion (Hu et al. 2015).

In an established TERT-overexpressing immortalised cell line (IHOK/TERT), TERT was responsible for the upregulation of the cysteine protease cathepsin D through the regulation of EGT1 that activates invasiveness and

Published by Bioscientifica Ltd 
cancer progression (Park et al. 2016). Downregulation of TERT during interferon gamma (IFNg) treatment in human glioblastoma SNB-19 and LN-18 cell lines, effectively inhibited angiogenesis and tumour progression (George et al. 2009).

Another study established the relationship between the activation of NF- $\mathrm{BB}$ signalling pathway and upregulation of the metalloproteinases (MMPs) 1, 3, 9 and 10 with enhancement of invasion. Ectopic expression of TERT and its catalytic mutant TERT K626A induced cancer cell invasion, MMP 9 mRNA expression and promoter activity in an NF-кB-dependent manner, regulating several target genes of this signalling pathway (Ding et al. 2013).

It seems that TERT has a role in the epithelialmesenchymal transition (EMT) process. TERT has a pivotal role in invasion and metastasis in stress hormone norepinephrine (NE)-induced ovarian cancer (Choi et al. 2015). NE induces TERT expression, Slug expression and ovarian cancer cell EMT and invasion (Choi et al. 2015). In colorectal cancer cell lines HCT116 and SW480, TERT and ZEB1 form a complex, which directly binds to the E-cadherin promoter, inhibiting E-cadherin expression and promoting EMT, thus promoting metastasis (Qin et al. 2016). In gastric cancer, TERT cooperates with transforming growth factor B1 (TGFB1) and B-Catenin in the promotion of EMT and stemness of gastric cancer cells (Liu et al. 2013c).

The main interactions of TERT with proliferation, invasion and metastisation are summarised in Table 2.

\section{Functional effects of TERT promoter mutations in tumours and cell lines}

TERT promoter mutations add a new dimension in the regulation of the TERT gene, due to the creation of new consensus binding sites for transcription factors. In the absence of mutations, and as discussed previously, it was shown that TERT can affect several pathways and is involved in tumorigenesis, proliferation, invasion and metastisation. The challenge, now, is to clarify how much these mutations can affect TERT interaction with other transcription factors and signalling pathways. As result of such, it would be interesting to understand how such mutations contribute through telomerase activity towards an immortalisation role. The main effects of TERT promoter mutations are summarised in Table 3.

Using the new tool, CRISPR/Cas9, to study the recurrent mutations in the TERT promoter, $\mathrm{Xi}$ and coworkers (Xi et al. 2015) verified that reverting the $-124 \mathrm{C}>\mathrm{T}$ mutation in a urothelial cancer cell line leads to decreased telomerase levels, telomere shortening and reduced proliferation rate (Xi et al. 2015). These results suggest the causality of the mutation for telomerase activity, telomere length maintenance and cell growth rate (Xi et al. 2015).

Another study described similar results showing that TERT promoter mutations abrogate TERT silencing and impairs telomere shortening (Chiba et al. 2015). The authors proposed that cells with the mutant promoter fail to repress transcription of TERT as they differentiate, showing high levels of TERT expression, telomerase activity and aberrant long telomeres (Chiba et al. 2015). This suggests that TERT promoter mutations are sufficient, at least in certain conditions, to overcome the proliferative barrier imposed by telomere shortening without additional tumour-selected mutations, meaning that TERT promoter mutations can lead to cellular immortalisation and tumorigenesis of incipient cancer cells (Chiba et al. 2015).

In a study using 23 urothelial cancer cell lines, Borah and coworkers confirmed that TERT promoter mutations correlate with higher levels of TERT mRNA, TERT protein, telomerase enzymatic activity and telomere length (Borah et al. 2015). Furthermore, TERT promoter mutations also correlate with worse patient outcome and reduced disease-specific survival in two independent patient cohorts (Borah et al. 2015).

In bladder cancer, $\mathrm{Li}$ and coworkers (Li et al. 2015a) described that the $-124 \mathrm{C}>\mathrm{T}$ mutation frequently occurs in the cancer stem cells, whereas the insertion of this mutation in normal bladder cells leads to TERT overexpression and cellular transformation. The reversion of the $-124 \mathrm{C}>\mathrm{T}$ mutation in bladder cancer stem cells can abolish TERT expression to basal levels and obliterate tumour formation. On the other hand, the presence of the $-124 \mathrm{C}>\mathrm{T}$ mutation enhances TERT expression and telomerase activity, these features being consistent with clinical severity and prognosis of bladder cancer (Li et al. 2015a).

The functionality of these mutations is now starting to be unravelled; Bell and coworkers (Bell et al. 2015) proposed in a glioblastoma cell line model how these mutations can affect TERT reactivation through the binding of ETS transcription factors. They identified multimeric GA-binding protein (GABP) transcription factor as the critical ETS transcription factor activating TERT expression in the presence of the $-124 \mathrm{C}>\mathrm{T}$ and $-146 \mathrm{C}>\mathrm{T}$ mutations (Bell et al. 2015). Although many ETS transcription factors can bind to similar DNA sequence motifs, GABP seems to be able to bind to neighbouring ETS

Published by Bioscientifica Ltd. 
Table 2 Summary of interactions of TERT with proliferation, invasion and tumourigenesis.

Cell effects
Tumourigenesis and
cell proliferation

TERT status
TERT expression

TERT expression

TERT expression

TERT expression

Tumourigenesis and cell proliferation

Tumourigenesis and cell proliferation

Cell death

$$
\text { TERT expression }
$$

Cell death

Cell death

Invasion and metastisation
Mitochondrial TERT localization Mitochondrial TERT localization

Nuclear TERT localization

Nuclear TERT localization TERT expression

\section{Interaction effects}

Cellular transformation

Tumourigenic phenotype

Cancer stem cell formation

Susceptibility to develop cancer

Increased ability to proliferate

ow levels of p21

Freezing of the epigenomic state of young proliferative cells

Upregulation of cyclin D1

Cancer progression

P53+/- genetic background Increased tumourigenesis in aging organisms

Growth advantage

Elevated proliferation rates

Elevated p27 levels

Inhibition of TERT mRNA expression

and telomerase activity

Reduction ER-stress induced cell death

or DNA damage

Anti-apoptotic action at an early stage of cell death

Neuron survival promoting function in the developing brain

Increased susceptibility to mtDNA

damage

Reduction of mtDNA damage

Improvement of mitochondrial function

Higher protection from apoptosis

Prevention of nuclear DNA damage

Diminished mtDNA damage

Increase cell survival

Protection against cellular senescence

High DNA damage

Promotion of invasion and

metastisation

Inhibition of E-cadherin expression Induction of EMT and stemness of cells

Spontaneous development and

dissemination of T-cell lymphoma

Inhibition of angiogenesis and tumour progression

\section{References}

(Artandi et al. 2002)

(Stewart et al. 2002)

(Liu et al. 2013c)

(Okamoto et al. 2011)

(Gonzalez-Suarez et al. 2001)

(Flores et al. 2005)

(Gonzalez-Suarez et al. 2001)

(Lindvall et al. 2003)

(Sarin et al. 2005)

(Smith et al. 2003)

(Young et al. 2003)

(Jagadeesh and Banerjee 2006)

(Gonzalez-Suarez et al. 2002)

(Listerman et al. 2013)

(Hrdlickova et al. 2012)

(Lee et al. 2005)

(Zhou et al. 2014)

(Fu et al. 2000)

(Santos et al. 2004)

(Santos et al. 2006)

(Ahmed et al. 2008)

(Haendeler et al. 2009)

(Singhapol et al. 2013)

(Santos et al. 2004)

(Santos et al. 2006)

(Singhapol et al. 2013)

(Ding et al. 2013)

(Hu et al. 2015)

(Park et al. 2007)

(Park et al. 2016)

(Tang et al. 2016)

(Qin et al. 2016)

(Choi et al. 2015)

(Liu et al. 2013c)

(Canela et al. 2004)

(George et al. 2009) motifs as a heterotetrameric complex, using the tandem flanking native E26 transforming-specific motifs. Bell and coworkers proposed that TERT promoter mutations cooperate with both of these native ETS sites to recruit GABP and reactivate TERT transcription (Bell et al. 2015).

Another study in glioblastoma, reported that although the $-124 \mathrm{C}>\mathrm{T}$ and $-146 \mathrm{C}>\mathrm{T}$ mutations create similar

\begin{tabular}{|lr}
\hline http://jme.endocrinology-journals.org & ( 2017 Society for Endocrinology \\
DOI: $10.1530 / J M E-16-0195$ & Printed in Great Britain
\end{tabular}

binding motif sequences, they are distinct functionally (Li et al. 2015b). The $-146 \mathrm{C}>\mathrm{T}$ creates a specific binding site for $\mathrm{p} 52$ being driven by non-canonical NF-кB signalling pathway (Li et al. 2015b). Li and coworkers also elucidate that the binding of ETS alone is ineffective in the activation of TERT transcription in the $-146 \mathrm{C}>\mathrm{T}$ mutation ( $\mathrm{Li}$ et al. $2015 b)$. The stimulation of the non-canonical NF-кB

Published by Bioscientifica Ltd. 
Table 3 Summary of functional effects of TERT promoter mutations in tumours and cell lines.

\begin{tabular}{|c|c|}
\hline Alteration & Cell effect \\
\hline Presence of the mutations & $\begin{array}{l}\text { Higher levels of TERT mRNA } \\
\text { Increase of telomerase activity } \\
\text { Impair of telomere shortening } \\
\text { transcription } \\
\text { Abolishment of epigenetic silencing } \\
\text { of active chromatin } \\
\text { Mediation of long-range chromatin } \\
\text { interaction } \\
\text { Enrichment of active histone marks }\end{array}$ \\
\hline Presence of the mutations & $\begin{array}{l}\text { Patients poorer outcome } \\
\text { Reduced disease specific survival }\end{array}$ \\
\hline
\end{tabular}

$-124 \mathrm{C}>\mathrm{T}$ mutation: Binding of GABPA $-146 \mathrm{C}>\mathrm{T}$ mutation: Binding of NF-kB p52

Reversion of the mutation

Reactivation of TERT

Interaction with ETS factors

Activation of the non-canonical NF-kB pathway

Enhanced tumourigenesis

Enhanced proliferation

Increase of telomerase activity

Insertion of the mutation

Abrogation of TERT transcription silencing

Increase of telomerase activity Impair of telomere shortening Obliterate tumour formation GABPA binding

Upregulation of TERT via long-range interactions

Acquisition of active histone marks POL2 recruitment

Decrease of telomerase activity

Telomere shortening

Reduced proliferation rate

Abrogation of GABPA binding and

long-range interaction

Depletion of active histone marks

Suppression of TERT transcription

\section{References}

(Vinagre et al. 2013)

(Borah et al. 2015)

(Li et al. 2015a)

(Heidenreich et al. 2015)

(Stern et al. 2015)

(Griewank et al. 2014)

(Nagore et al. 2016)

(Populo et al. 2014)

(Batista et al. 2016)

(Mosrati et al. 2015)

(Simon et al. 2015)

(Yuan et al. 2016)

(Melo et al. 2014)

(Vinagre et al. 2013)

(Bell et al. 2015)

(Li et al. 2015b)

(Chiba et al. 2015)

(Li et al. 2015a)

(Akıncılar et al. 2016)

(Xi et al. 2015)

(Akıncılar et al. 2016) pathway selectively induces TERT mRNA expression in $-146 \mathrm{C}>\mathrm{T}$ mutant cells, in which the mutation creates a binding site specific for p52 that interacts with ETS factors ETS1/2 to mediate TERT reactivation (Li et al. 2015b). This study also reports that there is an enhanced tumorigenic and proliferative effect due to NF- $\mathrm{B}$ activation by the increase of telomerase activity dependent on the existence of $-146 \mathrm{C}>\mathrm{T}$ mutation ( $\mathrm{Li}$ et al. 2015b). The results of this work show for the first time the role of non-canonical $\mathrm{NF}-\kappa \mathrm{B}$ pathway in tumorigenesis and also elucidate a possible mechanism for TERT reactivation in cancers with -146C > T mutation (Li et al. 2015b).

Stern and coworkers (Stern et al. 2015) described another mechanism by which the presence of TERT promoter mutations can cause an epigenetic switch and monoallelic expression (Stern et al. 2015). They reported that RNA polymerase II had a strong preference to occupy the mutant $-124 \mathrm{C}>\mathrm{T}$ TERT promoter that exhibited the $\mathrm{H} 3 \mathrm{H} 4 \mathrm{me} 2 / 3$ mark of active chromatin and recruited the GABPA/B1 transcription factor. In contrast, the wildtype allele retained the H3K27me3 mark of epigenetic silencing. Stern and coworkers also (Stern et al. 2015) claimed that the TERT promoter mutations cause the mutated allele to remain selectively active, whereas the other allele becomes repressed (Stern et al. 2015).

Recently, Akıncilar and coworkers reported in several cell lines that the mutated TERT promoter recruitment of GABPA mediates long-range chromatin interaction 


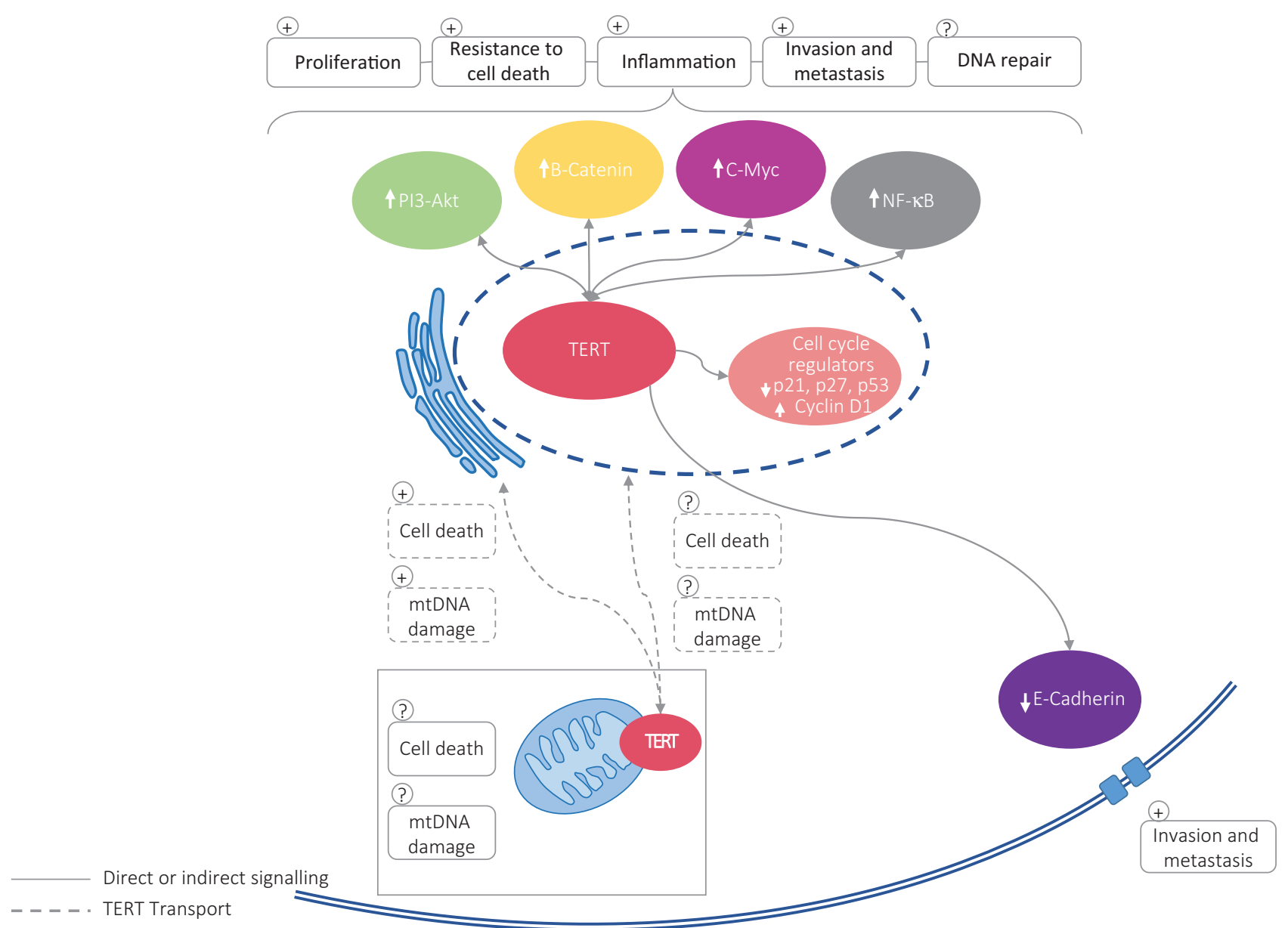

Figure 1

Representation of multiple interactions of TERT with several signalling pathways. TERT interaction with PI3-Akt, $\beta$-Catenin, c-MYC and NF-kB signalling pathways leads to increased proliferation, resistance to cell death, inflammation, invasion and metastasis. Repression (p21, p27 and p53) or overexpression (Cyclin D1) of cell cycle regulators by TERT leads to higher levels of proliferation and cell death resistance, by interfering with DNA repair checkpoints. It remains to be further elucidated if TERT localization in the mitochondria, nucleus or endoplasmic reticulum leads to higher/ lower levels of mtDNA and nDNA damage and cell death. TERT inhibits cell adhesion molecules, such as E-Cadherin, which gives cell higher capacities to invade and metastasize.

and enrichment of active histone marks, activating TERT transcription (Akıncilar et al. 2016). Reversal of the TERT promoter mutations, or deletion of its long-range interacting chromatin, abrogates GABPA binding and long-range interactions, leading to the depletion of active histone marks, loss of POL2 recruitment and suppression of TERT transcription. In contrast, the de novo insertion of the mutation in the TERT promoter allows GABPA binding and upregulation of TERT via long-range interactions, acquisition of active histone marks and subsequent POL2 recruitment (Akıncilar et al. 2016).

\section{Conclusions}

TERT promoter mutations represent a possible mechanism for telomerase reactivation and have been pointed so far as one of the most common events in several human cancers. Additionally, TERT has been described as having a key role in several signalling pathways that are frequently altered in cancer (Fig. 1).

Associations have been made in several cancers between the presence of TERT promoter mutations, TERT mRNA expression levels and aggressive clinicopathological features leading to a poorer outcome. Nevertheless, the biological bridge between the presence of TERT promoter mutations and the aggressive/invasive features displayed by the tumours remains partially unidentified. It is necessary to further understand the biological role of TERT promoter mutations in cancer, beyond the primordial mechanism of immortalisation, the telomere maintenance. One of the first steps is to understand the background of these mutations, i.e., how

Published by Bioscientifica Ltd 
these mutations reactivate TERT transcription, what are their effects on epigenetic regulation of the promoter, which transcription factors are able to bind to the new consensus site, and which regulators and targets of TERT are affected by the occurrence of these mutations. These mutations can also represent a mechanism that can interfere in TERT localisation within the cell, which could lead to mtDNA and nDNA damages as well as to metabolic alterations in cancer cells. In common with these scenarios we must have tumour cells with a genetic background prone to the expression of transcription factors for the newly generated binding sites. The presence of the mutations without the adequate repertoire of transcriptions factors would be redundant, and this preconditioned background could also be one of the reasons why TERT promoter mutations represent a growth advantage for certain cell types, i.e., tissue specificity.

Several questions remain unanswered in this field that has been awaked recently. The understanding of the presence of these mutations in the promoter could be one of the first steps to understand telomerase reactivation beyond its role in cell immortalisation.

\section{Declaration of interest}

The authors declare that there is no conflict of interest that could be perceived as prejudicing the impartiality of this review.

\section{Funding}

This study was supported by FCT, the Portuguese Foundation for Science and Technology through a PhD grant to A P SFRH/BD/110617/2015 and J V SFRH/BD/81940/2011. This work was financed by FEDER-Fundo Europeu de Desenvolvimento Regional funds through the COMPETE 2020Operacional Programme for Competitiveness and Internationalization (POCI), Portugal 2020, and by Portuguese funds through FCT-Fundação para a Ciência e a Tecnologia/Ministério da Ciência, Tecnologia e Inovação in the framework of the project 'Institute for Research and Innovation in Health Sciences' (POCl-01-0145-FEDER-007274). Further funding from the project 'Advancing cancer research: from basic knowledgment to application'; NORTE-01-0145-FEDER-000029; and 'Projetos Estruturados de I\&D\&I', funded by Norte 2020_-Programa Operacional Regional do Norte.

Author contribution statement

All authors were involved in the manuscript preparation.

\section{References}

Ahmed S, Passos JF, Birket MJ, Beckmann T, Brings S, Peters $\mathrm{H}$ Birch-Machin MA, von Zglinicki T \& Saretzki G 2008 Telomerase does not counteract telomere shortening but protects mitochondrial function under oxidative stress. Journal of Cell Science 121 1046-1053. (doi:10.1242/jcs.019372)

Akıncilar SC, Khattar E, Boon PL, Unal B, Fullwood MJ \& Tergaonkar V 2016 Long-range chromatin interactions drive mutant TERT promoter activation. Cancer Discovery 6 1276-1291. (doi:10.1158/2159-8290.CD-16-0177)

Akiyama M, Hideshima T, Hayashi T, Tai YT, Mitsiades CS, Mitsiades N Chauhan D, Richardson P, Munshi NC \& Anderson KC 2002 Cytokines modulate telomerase activity in a human multiple myeloma cell line. Cancer Research 62 3876-3882.

Akiyama M, Hideshima T, Hayashi T, Tai YT, Mitsiades CS, Mitsiades N, Chauhan D, Richardson P, Munshi NC \& Anderson KC 2003 Nuclear factor-kappaB p65 mediates tumor necrosis factor alpha-induced nuclear translocation of telomerase reverse transcriptase protein. Cancer Research 63 18-21.

Allory Y, Beukers W, Sagrera A, Flandez M, Marques M, Marquez M, van der Keur KA, Dyrskjot L, Lurkin I, Vermeij M, et al. 2014 Telomerase reverse transcriptase promoter mutations in bladder cancer: high frequency across stages, detection in urine, and lack of association with outcome. European Urology 65 360-366. (doi:10.1016/j.eururo.2013.08.052)

Amor S, Remy S, Dambrine G, Le Vern Y, Rasschaert D \& Laurent S 2010 Alternative splicing and nonsense-mediated decay regulate telomerase reverse transcriptase (TERT) expression during virusinduced lymphomagenesis in vivo. BMC Cancer 10571. (doi:10.1186/1471-2407-10-571)

Aogi K, Kitahara K, Urquidi V, Tarin D \& Goodison S 1999 Comparison of telomerase and CD44 expression as diagnostic tumor markers in lesions of the thyroid. Clinical Cancer Research 5 2790-2797.

Artandi SE, Alson S, Tietze MK, Sharpless NE, Ye S, Greenberg RA, Castrillon DH, Horner JW, Weiler SR, Carrasco RD, et al. 2002 Constitutive telomerase expression promotes mammary carcinomas in aging mice. PNAS 99 8191-8196. (doi:10.1073/pnas.112515399)

Batista R, Cruvinel-Carloni A, Vinagre J, Peixoto J, Catarino TA, Campanella NC, Menezes W, Becker AP, de Almeida GC, Matsushita MM, et al. 2016 The prognostic impact of TERT promoter mutations in glioblastomas is modified by the rs2853669 single nucleotide polymorphism. International Journal of Cancer 139 414-423. (doi:10.1002/ijc.30057)

Beattie TL, Zhou W, Robinson MO \& Harrington L 1998 Reconstitution of human telomerase activity in vitro. Current Biology 8 177-180. (doi:10.1016/S0960-9822(98)70067-3)

Bell RJ, Rube HT, Kreig A, Mancini A, Fouse SD, Nagarajan RP, Choi S Hong C, He D, Pekmezci M, et al. 2015 Cancer. The transcription factor GABP selectively binds and activates the mutant TERT promoter in cancer. Science 348 1036-1039. (doi:10.1126/science. aab0015)

Blackburn EH 1991 Structure and function of telomeres. Nature 350 569-573. (doi:10.1038/350569a0)

Blackburn EH 2001 Switching and signaling at the telomere. Cell 106 661-673. (doi:10.1016/S0092-8674(01)00492-5)

Boaventura P, Batista R, Pestana A, Reis M, Mendes A, Eloy C, Sobrinho-Simoes M \& Soares P 2016 TERT promoter mutations: a genetic signature of benign and malignant thyroid tumours occurring in the context of tinea capitis irradiation. European Journal of Endocrinology 176 49-55. (doi:10.1530/EJE-16-0740)

Borah S, Xi L, Zaug AJ, Powell NM, Dancik GM, Cohen SB, Costello JC, Theodorescu D \& Cech TR 2015 Cancer. TERT promoter mutations and telomerase reactivation in urothelial cancer. Science $\mathbf{3 4 7}$ 1006-1010. (doi:10.1126/science.1260200)

Broccoli D, Young JW \& de Lange T 1995 Telomerase activity in normal and malignant hematopoietic cells. PNAS 92 9082-9086. (doi:10.1073/pnas.92.20.9082)

Bryce LA, Morrison N, Hoare SF, Muir S \& Keith WN 2000 Mapping of the gene for the human telomerase reverse transcriptase, hTERT, to chromosome 5 p15.33 by fluorescence in situ hybridization. Neoplasia 2 197-201. (doi:10.1038/sj.neo.7900092)

Bu DX, Johansson ME, Ren J, Xu DW, Johnson FB, Edfeldt K \& Yan ZQ 2010 Nuclear factor $\{$ kappa\}B-mediated transactivation of telomerase prevents intimal smooth muscle cell from replicative senescence

Published by Bioscientifica Ltd. 
during vascular repair. Arteriosclerosis, Thrombosis, and Vascular Biology 30 2604-2610. (doi:10.1161/ATVBAHA.110.213074)

Canela A, Martin-Caballero J, Flores JM \& Blasco MA 2004 Constitutive expression of tert in thymocytes leads to increased incidence and dissemination of T-cell lymphoma in Lck-Tert mice. Molecular and Cellular Biology 24 4275-4293. (doi:10.1128/MCB.24.10.42754293.2004)

Chang H \& Delany ME 2006 Complicated RNA splicing of chicken telomerase reverse transcriptase revealed by profiling cells both positive and negative for telomerase activity. Gene 379 33-39. (doi:10.1016/j.gene.2006.04.021)

Chiba K, Johnson JZ, Vogan JM, Wagner T, Boyle JM \& Hockemeyer D 2015 Cancer-associated TERT promoter mutations abrogate telomerase silencing. eLife 4 e07918. (doi:10.7554/elife.07918)

Chiu CP, Dragowska W, Kim NW, Vaziri H, Yui J, Thomas TE, Harley CB \& Lansdorp PM 1996 Differential expression of telomerase activity in hematopoietic progenitors from adult human bone marrow. Stem Cells 14 239-248. (doi:10.1002/stem.140239)

Choi MJ, Cho KH, Lee S, Bae YJ, Jeong KJ, Rha SY, Choi EJ, Park JH, Kim JM, Lee JS, et al. 2015 hTERT mediates norepinephrine-induced Slug expression and ovarian cancer aggressiveness. Oncogene $\mathbf{3 4}$ 3402-3412. (doi:10.1038/onc.2014.270)

Cifuentes-Rojas C \& Shippen DE 2012 Telomerase regulation. Mutation Research 730 20-27. (doi:10.1016/j.mrfmmm.2011.10.003)

Cong YS, Wen J \& Bacchetti S 1999 The human telomerase catalytic subunit hTERT: organization of the gene and characterization of the promoter. Human Molecular Genetics 8 137-142. (doi:10.1093/ $\mathrm{hmg} / 8.1 .137)$

Cong YS, Wright WE \& Shay JW 2002 Human telomerase and its regulation. Microbiology and Molecular Biology Reviews 66 407-425. (doi:10.1128/mmbr.66.3.407-425.2002)

Crescenzi A, Trimboli P, Modica DC, Taffon C, Guidobaldi L, Taccogna S, Rainer A, Trombetta M, Papini E \& Zelano G 2016 Preoperative assessment of TERT promoter mutation on thyroid core needle biopsies supports diagnosis of malignancy and addresses surgical strategy. Hormone and Metabolic Research 48 157-162. (doi:10.1055/s-0035-1548873)

Cukusic A, Skrobot Vidacek N, Sopta M \& Rubelj I 2008 Telomerase regulation at the crossroads of cell fate. Cytogenetic and Genome Research 122 263-272. (doi:10.1159/000167812)

Ding D, Xi P, Zhou J, Wang M \& Cong YS 2013 Human telomerase reverse transcriptase regulates MMP expression independently of telomerase activity via NF-kappaB-dependent transcription. FASEB Journal 27 4375-4383. (doi:10.1096/fj.13-230904)

Dumont JE, Maenhaut C, Pirson I, Baptist M \& Roger PP 1991 Growth factors controlling the thyroid gland. Bailliere's Clinical Endocrinology and Metabolism 5 727-754. (doi:10.1016/s0950$351 \times(10) 80012-6)$

Flores I, Cayuela ML \& Blasco MA 2005 Effects of telomerase and telomere length on epidermal stem cell behavior. Science 309 1253-1256. (doi:10.1126/science.1115025)

Fu W, Killen M, Culmsee C, Dhar S, Pandita TK \& Mattson MP 2000 The catalytic subunit of telomerase is expressed in developing brain neurons and serves a cell survival-promoting function. Journal of Molecular Neuroscience 14 3-15. (doi:10.1385/JMN:14:1-2:003)

George J, Banik NL \& Ray SK 2009 Combination of hTERT knockdown and IFN-gamma treatment inhibited angiogenesis and tumor progression in glioblastoma. Clinical Cancer Research 15 7186-7195. (doi:10.1158/1078-0432.CCR-09-1425)

George JR, Henderson YC, Williams MD, Roberts DB, Hei H, Lai SY \& Clayman GL 2015 Association of TERT promoter mutation, but not BRAF mutation, with increased mortality in PTC. Journal of Clinical Endocrinology and Metabolism 100 E1550-E1559. (doi:10.1210/ jc.2015-2690)

Ghosh A, Saginc G, Leow SC, Khattar E, Shin EM, Yan TD, Wong M, Zhang Z, Li G, Sung WK, et al. 2012 Telomerase directly regulates
NF-kappaB-dependent transcription. Nature Cell Biology 14 1270-1281. (doi:10.1038/ncb2621)

Gonzalez-Suarez E, Samper E, Ramirez A, Flores JM, Martin-Caballero J, Jorcano JL \& Blasco MA 2001 Increased epidermal tumors and increased skin wound healing in transgenic mice overexpressing the catalytic subunit of telomerase, mTERT, in basal keratinocytes. EMBO Journal 20 2619-2630. (doi:10.1093/emboj/20.11.2619)

Gonzalez-Suarez E, Flores JM \& Blasco MA 2002 Cooperation between p53 mutation and high telomerase transgenic expression in spontaneous cancer development. Molecular and Cellular Biology 22 7291-7301. (doi:10.1128/MCB.22.20.7291-7301.2002)

Gordon DM \& Santos JH 2010 The emerging role of telomerase reverse transcriptase in mitochondrial DNA metabolism. Journal of Nucleic Acids 2010 article ID 390791. (doi:10.4061/2010/390791)

Greenberg RA, O'Hagan RC, Deng H, Xiao Q, Hann SR, Adams RR, Lichtsteiner S, Chin L, Morin GB \& DePinho RA 1999 Telomerase reverse transcriptase gene is a direct target of c-Myc but is not functionally equivalent in cellular transformation. Oncogene $\mathbf{1 8}$ 1219-1226. (doi:10.1038/sj.onc.1202669)

Greider CW 1991 Telomerase is processive. Molecular and Cellular Biology 11 4572-4580. (doi:10.1128/MCB.11.9.4572)

Greider CW \& Blackburn EH 1989 A telomeric sequence in the RNA of Tetrahymena telomerase required for telomere repeat synthesis. Nature 337 331-337. (doi:10.1038/337331a0)

Griewank KG, Murali R, Puig-Butille JA, Schilling B, Livingstone E, Potrony M, Carrera C, Schimming T, Moller I, Schwamborn M, et al. 2014 TERT promoter mutation status as an independent prognostic factor in cutaneous melanoma. Journal of the National Cancer Institute 106 dju246. (doi:10.1093/jnci/dju246)

Haendeler J, Drose S, Buchner N, Jakob S, Altschmied J, Goy C, Spyridopoulos I, Zeiher AM, Brandt U \& Dimmeler S 2009 Mitochondrial telomerase reverse transcriptase binds to and protects mitochondrial DNA and function from damage. Arteriosclerosis, Thrombosis, and Vascular Biology 29 929-935. (doi:10.1161/ ATVBAHA.109.185546)

Hayflick L 1965 The limited in vitro lifetime of human diploid cell strains. Experimental Cell Research 37 614-636. (doi:10.1016/00144827(65)90211-9)

Hegedus L 2004 Clinical practice. The thyroid nodule. New England Journal of Medicine 351 1764-1771. (doi:10.1056/ NEJMcp031436)

Heidenreich B, Nagore E, Rachakonda PS, Garcia-Casado Z, Requena C, Traves V, Becker J, Soufir N, Hemminki K \& Kumar R 2014 Telomerase reverse transcriptase promoter mutations in primary cutaneous melanoma. Nature Communications 5 3401. (doi:10.1038/ ncomms4401)

Heidenreich B, Rachakonda PS, Hosen I, Volz F, Hemminki K, Weyerbrock A \& Kumar R 2015 TERT promoter mutations and telomere length in adult malignant gliomas and recurrences. Oncotarget 6 10617-10633. (doi:10.18632/oncotarget.3329)

Hisatomi H, Ohyashiki K, Ohyashiki JH, Nagao K, Kanamaru T, Hirata H, Hibi N \& Tsukada Y 2003 Expression profile of a gamma-deletion variant of the human telomerase reverse transcriptase gene. Neoplasia 5 193-197. (doi:10.1016/S1476-5586(03)80051-9)

Hoang-Vu C, Boltze C, Gimm O, Poremba C, Dockhorn-Dworniczak B, Kohrle J, Rath FW \& Dralle H 2002 Expression of telomerase genes in thyroid carcinoma. International Journal of Oncology 21 265-272. (doi:10.3892/ijo.21.2.265)

Hoffmeyer K, Raggioli A, Rudloff S, Anton R, Hierholzer A, Del Valle I, Hein K, Vogt R \& Kemler R 2012 Wnt/beta-catenin signaling regulates telomerase in stem cells and cancer cells. Science $\mathbf{3 3 6}$ 1549-1554. (doi:10.1126/science.1218370)

Horn S, Figl A, Rachakonda PS, Fischer C, Sucker A, Gast A, Kadel S, Moll I, Nagore E, Hemminki K, et al. 2013 TERT promoter mutations in familial and sporadic melanoma. Science 339 959-961. (doi:10.1126/science.1230062)

Published by Bioscientifica Ltd. 
Hrdlickova R, Nehyba J \& Bose HR Jr 2012 Alternatively spliced telomerase reverse transcriptase variants lacking telomerase activity stimulate cell proliferation. Molecular and Cellular Biology 32 4283-4296. (doi:10.1128/MCB.00550-12)

Hu C, Ni Z, Li BS, Yong X, Yang X, Zhang JW, Zhang D, Qin Y, Jie MM, Dong H, et al. 2015 hTERT promotes the invasion of gastric cancer cells by enhancing FOXO3a ubiquitination and subsequent ITGB1 upregulation. Gut 66 31-42. (doi:10.1136/ gutjnl-2015-309322)

Huang FW, Hodis E, Xu MJ, Kryukov GV, Chin L \& Garraway LA 2013 Highly recurrent TERT promoter mutations in human melanoma. Science 339 957-959. (doi:10.1126/science.1229259)

Hurst CD, Platt FM \& Knowles MA 2014 Comprehensive mutation analysis of the TERT promoter in bladder cancer and detection of mutations in voided urine. European Urology 65 367-369. (doi:10.1016/j.eururo.2013.08.057)

Ishikawa F 1997 Regulation mechanisms of mammalian telomerase. A review. Biochemistry 62 1332-1337.

Jagadeesh S \& Banerjee PP 2006 Telomerase reverse transcriptase regulates the expression of a key cell cycle regulator, cyclin D1. Biochemical and Biophysical Research Communications 347 774-780. (doi:10.1016/j.bbrc.2006.06.172)

Kilian A, Bowtell DD, Abud HE, Hime GR, Venter DJ, Keese PK, Duncan EL, Reddel RR \& Jefferson RA 1997 Isolation of a candidate human telomerase catalytic subunit gene, which reveals complex splicing patterns in different cell types. Human Molecular Genetics 6 2011-2019. (doi:10.1093/hmg/6.12.2011)

Killela PJ, Reitman ZJ, Jiao Y, Bettegowda C, Agrawal N, Diaz LA Jr, Friedman AH, Friedman H, Gallia GL, Giovanella BC, et al. 2013 TERT promoter mutations occur frequently in gliomas and a subset of tumors derived from cells with low rates of self-renewal. PNAS 110 6021-6026. (doi:10.1073/pnas.1303607110)

Kim NW, Piatyszek MA, Prowse KR, Harley CB, West MD, Ho PL, Coviello GM, Wright WE, Weinrich SL \& Shay JW 1994 Specific association of human telomerase activity with immortal cells and cancer. Science 266 2011-2015. (doi:10.1126/science.7605428)

Koh CM, Khattar E, Leow SC, Liu CY, Muller J, Ang WX, Li Y, Franzoso G, Li S, Guccione E, et al. 2015 Telomerase regulates MYC-driven oncogenesis independent of its reverse transcriptase activity. Journal of Clinical Investigation 125 2109-2122. (doi:10.1172/ JCI79134)

La Vecchia C, Malvezzi M, Bosetti C, Garavello W, Bertuccio P, Levi F \& Negri E 2015 Thyroid cancer mortality and incidence: a global overview. International Journal of Cancer 136 2187-2195. (doi:10.1002/ijc.29251)

Landa I, Ganly I, Chan TA, Mitsutake N, Matsuse M, Ibrahimpasic T, Ghossein RA \& Fagin JA 2013 Frequent somatic TERT promoter mutations in thyroid cancer: higher prevalence in advanced forms of the disease. Journal of Clinical Endocrinology and Metabolism 98 E1562-E1566. (doi:10.1210/jc.2013-2383)

Landa I, Ibrahimpasic T, Boucai L, Sinha R, Knauf JA, Shah RH, Dogan S, Ricarte-Filho JC, Krishnamoorthy GP, Xu B, et al. 2016 Genomic and transcriptomic hallmarks of poorly differentiated and anaplastic thyroid cancers. Journal of Clinical Investigation 126 1052-1066. (doi:10.1172/JCI85271)

Lee SH, Kim JW, Oh SH, Kim YJ, Rho SB, Park K, Park KL \& Lee JH 2005 IFN-gamma/IRF-1-induced p27kip1 down-regulates telomerase activity and human telomerase reverse transcriptase expression in human cervical cancer. FEBS Letters 579 1027-1033. (doi:10.1016/j. febslet.2005.01.005)

Lendvay TS, Morris DK, Sah J, Balasubramanian B \& Lundblad V 1996 Senescence mutants of Saccharomyces cerevisiae with a defect in telomere replication identify three additional EST genes. Genetics 144 1399-1412.

Li C, Wu MY, Liang YR \& Wu XY 2003 Correlation between expression of human telomerase subunits and telomerase activity in esophageal squamous cell carcinoma. World Journal of Gastroenterology 9 2395-2399. (doi:10.3748/wjg.v9.i11.2395)

Li C, Wu S, Wang H, Bi X, Yang Z, Du Y, He L, Cai Z, Wang J \& Fan Z $2015 a$ The C228T mutation of TERT promoter frequently occurs in bladder cancer stem cells and contributes to tumorigenesis of bladder cancer. Oncotarget 6 19542-19551. (doi:10.18632/ oncotarget.4295)

Li Y, Zhou QL, Sun W, Chandrasekharan P, Cheng HS, Ying Z, Lakshmanan M, Raju A, Tenen DG, Cheng SY, et al. 2015b Non-canonical NF-kappaB signalling and ETS1/2 cooperatively drive C250T mutant TERT promoter activation. Nature Cell Biology 17 1327-1338. (doi:10.1038/ncb3240)

Lindvall C, Hou M, Komurasaki T, Zheng C, Henriksson M, Sedivy JM, Bjorkholm M, Teh BT, Nordenskjold M \& Xu D 2003 Molecular characterization of human telomerase reverse transcriptaseimmortalized human fibroblasts by gene expression profiling: activation of the epiregulin gene. Cancer Research $\mathbf{6 3} 1743-1747$.

Lingner J \& Cech TR 1996 Purification of telomerase from Euplotes aediculatus: requirement of a primer 3' overhang. PNAS 93 10712-10717. (doi:10.1073/pnas.93.20.10712)

Listerman I, Sun J, Gazzaniga FS, Lukas JL \& Blackburn EH 2013 The major reverse transcriptase-incompetent splice variant of the human telomerase protein inhibits telomerase activity but protects from apoptosis. Cancer Research 73 2817-2828. (doi:10.1158/0008-5472. CAN-12-3082)

Listerman I, Gazzaniga FS \& Blackburn EH 2014 An investigation of the effects of the core protein telomerase reverse transcriptase on Wnt signaling in breast cancer cells. Molecular and Cellular Biology $\mathbf{3 4}$ 280-289. (doi:10.1128/MCB.00844-13)

Liu R \& Xing M 2014 Diagnostic and prognostic TERT promoter mutations in thyroid fine-needle aspiration biopsy. Endocrine-Related Cancer 21 825-830. (doi:10.1530/ERC-14-0359)

Liu L, Lai S, Andrews LG \& Tollefsbol TO 2004 Genetic and epigenetic modulation of telomerase activity in development and disease. Gene 340 1-10. (doi:10.1016/j.gene.2004.06.011)

Liu T, Wang N, Cao J, Sofiadis A, Dinets A, Zedenius J, Larsson C \& Xu D 2013a The age- and shorter telomere-dependent TERT promoter mutation in follicular thyroid cell-derived carcinomas. Oncogene 33 4978-4984. (doi:10.1038/onc.2013.446)

Liu X, Wu G, Shan Y, Hartmann C, von Deimling A \& Xing M 2013b Highly prevalent TERT promoter mutations in bladder cancer and glioblastoma. Cell Cycle 12 1637-1638. (doi:10.4161/cc.24662)

Liu X, Bishop J, Shan Y, Pai S, Liu D, Murugan AK, Sun H, El-Naggar AK \& Xing M 2013c Highly prevalent TERT promoter mutations in aggressive thyroid cancers. Endocrine-Related Cancer 20 603-610. (doi:10.1530/ERC-13-0210)

Liu Z, Li Q, Li K, Chen L, Li W, Hou M, Liu T, Yang J, Lindvall C, Bjorkholm M, et al. 2013d Telomerase reverse transcriptase promotes epithelial-mesenchymal transition and stem cell-like traits in cancer cells. Oncogene 32 4203-4213. (doi:10.1038/onc.2012.441)

Liu X, Qu S, Liu R, Sheng C, Shi X, Zhu G, Murugan AK, Guan H, Yu $\mathrm{H}$, Wang $\mathrm{Y}$, et al. 2014 TERT promoter mutations and their association with BRAF V600E mutation and aggressive clinicopathological characteristics of thyroid cancer. Journal of Clinical Endocrinology and Metabolism 99 E1130-E1136. (doi:10.1210/jc.2013-4048)

Liu R, Bishop J, Zhu G, Zhang T, Ladenson PW \& Xing M $2016 a$ Mortality risk stratification by combining BRAF V600E and TERT promoter mutations in papillary thyroid cancer: genetic duet of BRAF and TERT promoter mutations in thyroid cancer mortality. JAMA Oncology [in press]. (doi:10.1001/jamaoncol.2016.3288)

Liu W, Yin Y, Wang J, Shi B, Zhang L, Qian D, Li C, Zhang H, Wang S, Zhu J, et al. $2016 b$ Kras mutations increase telomerase activity and targeting telomerase is a promising therapeutic strategy for Krasmutant NSCLC. Oncotarget 8 179-190. (doi:10.18632/ oncotarget.10162) 
Macerola E, Loggini B, Giannini R, Garavello G, Giordano M, Proietti A, Niccoli C, Basolo F \& Fontanini G 2015 Coexistence of TERT promoter and BRAF mutations in cutaneous melanoma is associated with more clinicopathological features of aggressiveness. Virchows Archiv 467 177-184. (doi:10.1007/s00428-015-1784-x)

Makarov VL, Hirose Y \& Langmore JP 1997 Long G tails at both ends of human chromosomes suggest a $\mathrm{C}$ strand degradation mechanism for telomere shortening. Cell 88 657-666. (doi:10.1016/S00928674(00)81908-X)

Masutomi K, Possemato R, Wong JM, Currier JL, Tothova Z, Manola JB, Ganesan S, Lansdorp PM, Collins K \& Hahn WC 2005 The telomerase reverse transcriptase regulates chromatin state and DNA damage responses. PNAS 102 8222-8227. (doi:10.1073/ pnas.0503095102)

Mattiussi M, Tilman G, Lenglez S \& Decottignies A 2012 Human telomerase represses ROS-dependent cellular responses to Tumor Necrosis Factor-alpha without affecting NF-kappaB activation. Cellular Signalling 24 708-717. (doi:10.1016/j.cellsig.2011.11.004)

Melo M, da Rocha AG, Vinagre J, Batista R, Peixoto J, Tavares C, Celestino R, Almeida A, Salgado C, Eloy C, et al. 2014 TERT promoter mutations are a major indicator of poor outcome in differentiated thyroid carcinomas. Journal of Clinical Endocrinology and Metabolism 99 E754-E765. (doi:10.1210/jc.2013-3734)

Melo M, da Rocha AG, Vinagre J, Sobrinho-Simoes M \& Soares P 2015 Coexistence of TERT promoter and BRAF mutations in papillary thyroid carcinoma: added value in patient prognosis? Journal of Clinical Oncology 33 667-668. (doi:10.1200/JCO.2014.59.4614)

Meyerson M, Counter CM, Eaton EN, Ellisen LW, Steiner P, Caddle SD, Ziaugra L, Beijersbergen RL, Davidoff MJ, Liu Q, et al. 1997 hEST2, the putative human telomerase catalytic subunit gene, is up-regulated in tumor cells and during immortalization. Cell 90 785-795. (doi:10.1016/S0092-8674(00)80538-3)

Morrison SJ, Prowse KR, Ho P \& Weissman IL 1996 Telomerase activity in hematopoietic cells is associated with self-renewal potential. Immunity 5 207-216. (doi:10.1016/S1074-7613(00)80316-7)

Mosrati MA, Malmstrom A, Lysiak M, Krysztofiak A, Hallbeck M, Milos P, Hallbeck AL, Bratthall C, Strandeus M, Stenmark-Askmalm M, et al. 2015 TERT promoter mutations and polymorphisms as prognostic factors in primary glioblastoma. Oncotarget 6 16663-16673. (doi:10.18632/oncotarget.4389)

Moyzis RK, Buckingham JM, Cram LS, Dani M, Deaven LL, Jones MD, Meyne J, Ratliff RL \& Wu JR 1988 A highly conserved repetitive DNA sequence, (TTAGGG)n, present at the telomeres of human chromosomes. PNAS 85 6622-6626. (doi:10.1073/ pnas.85.18.6622)

Mukherjee S, Firpo EJ, Wang Y \& Roberts JM 2011 Separation of telomerase functions by reverse genetics. PNAS 108 E1363-E1371. (doi:10.1073/pnas.1112414108)

Muzza M, Colombo C, Rossi S, Tosi D, Cirello V, Perrino M, De Leo S, Magnani E, Pignatti E, Vigo B, et al. 2015 Telomerase in differentiated thyroid cancer: promoter mutations, expression and localization. Molecular and Cellular Endocrinology 399 288-295. (doi:10.1016/j.mce.2014.10.019)

Muzza M, Colombo C, Cirello V, Perrino M, Vicentini L \& Fugazzola L 2016 Oxidative stress and the subcellular localization of the telomerase reverse transcriptase (TERT) in papillary thyroid cancer. Molecular and Cellular Endocrinology 431 54-61. (doi:10.1016/j. mce.2016.05.005)

Nagore E, Heidenreich B, Rachakonda S, Garcia-Casado Z, Requena C, Soriano V, Frank C, Traves V, Quecedo E, Sanjuan-Gimenez J, et al. 2016 TERT promoter mutations in melanoma survival. International Journal of Cancer 139 75-84. (doi:10.1002/ijc.30042)

Nakamura TM, Morin GB, Chapman KB, Weinrich SL, Andrews WH, Lingner J, Harley CB \& Cech TR 1997 Telomerase catalytic subunit homologs from fission yeast and human. Science 277 955-959. (doi:10.1126/science.277.5328.955)
Nasirden A, Saito T, Fukumura Y, Hara K, Akaike K, Kurisaki-Arakawa A, Asahina M, Yamashita A, Tomomasa R, Hayashi T, et al. 2016 In Japanese patients with papillary thyroid carcinoma, TERT promoter mutation is associated with poor prognosis, in contrast to BRAF V600E mutation. Virchows Archiv 469 687-696. (doi:10.1007/s00428016-2027-5)

Nault JC, Mallet M, Pilati C, Calderaro J, Bioulac-Sage P, Laurent C, Laurent A, Cherqui D, Balabaud C \& Zucman-Rossi J 2013 High frequency of telomerase reverse-transcriptase promoter somatic mutations in hepatocellular carcinoma and preneoplastic lesions. Nature Communications 4 2218. (doi:10.1038/ncomms3218)

Oikawa T \& Yamada T 2003 Molecular biology of the Ets family of transcription factors. Gene 303 11-34. (doi:10.1016/S03781119(02)01156-3)

Okamoto N, Yasukawa M, Nguyen C, Kasim V, Maida Y, Possemato R, Shibata T, Ligon KL, Fukami K, Hahn WC, et al. 2011 Maintenance of tumor initiating cells of defined genetic composition by nucleostemin. PNAS 108 20388-20393. (doi:10.1073/ pnas.1015171108)

Olovnikov AM 1973 A theory of marginotomy. The incomplete copying of template margin in enzymic synthesis of polynucleotides and biological significance of the phenomenon. Journal of Theoretical Biology 41 181-190. (doi:10.1016/0022-5193(73)90198-7)

Park YP, Choi SC, Kim JH, Song EY, Kim JW, Yoon DY, Yeom YI, Lim JS, Kim JW, Paik SG, et al. 2007 Up-regulation of Mac-2 binding protein by hTERT in gastric cancer. International Journal of Cancer $\mathbf{1 2 0}$ 813-820. (doi:10.1002/ijc.22369)

Park JI, Venteicher AS, Hong JY, Choi J, Jun S, Shkreli M, Chang W, Meng Z, Cheung P, Ji H, et al. 2009 Telomerase modulates Wnt signalling by association with target gene chromatin. Nature $\mathbf{4 6 0}$ 66-72. (doi:10.1038/nature08137)

Park YJ, Kim EK, Bae JY, Moon S \& Kim J 2016 Human telomerase reverse transcriptase (hTERT) promotes cancer invasion by modulating cathepsin D via early growth response (EGR)-1. Cancer Letters 370 222-231. (doi:10.1016/j.canlet.2015.10.021)

Populo H, Boaventura P, Vinagre J, Batista R, Mendes A, Caldas R, Pardal J, Azevedo F, Honavar M, Guimaraes I, et al. 2014 TERT promoter mutations in skin cancer: the effects of sun exposure and X-irradiation. Journal of Investigative Dermatology 134 2251-2257. (doi:10.1038/jid.2014.163)

Preto A, Cameselle-Teijeiro J, Moldes-Boullosa J, Soares P, Cameselle-Teijeiro JF, Silva P, Reis-Filho JS, Reyes-Santias RM, Alfonsin-Barreiro N, Forteza J, et al. 2004 Telomerase expression and proliferative activity suggest a stem cell role for thyroid solid cell nests. Modern Pathology 17 819-826. (doi:10.1038/ modpathol.3800124)

Qasem E, Murugan AK, Al-Hindi H, Xing M, Almohanna M, Alswailem M \& Alzahrani AS 2015 TERT promoter mutations in thyroid cancer: a report from a Middle Eastern population. Endocrine-Related Cancer 22 901-908. (doi:10.1530/erc-15-0396)

Qin Y, Tang B, Hu CJ, Xiao YF, Xie R, Yong X, Wu YY, Dong H \& Yang SM 2016 An hTERT/ZEB1 complex directly regulates E-cadherin to promote epithelial-to-mesenchymal transition (EMT) in colorectal cancer. Oncotarget 7 351-361. (doi:10.18632/oncotarget.5968)

Rachakonda PS, Hosen I, de Verdier PJ, Fallah M, Heidenreich B, Ryk C, Wiklund NP, Steineck G, Schadendorf D, Hemminki K, et al. 2013 TERT promoter mutations in bladder cancer affect patient survival and disease recurrence through modification by a common polymorphism. PNAS 110 17426-17431. (doi:10.1073/ pnas.1310522110)

Reis-Filho JS, Preto A, Soares P, Ricardo S, Cameselle-Teijeiro J \& Sobrinho-Simoes M 2003 p63 expression in solid cell nests of the thyroid: further evidence for a stem cell origin. Modern Pathology 16 43-48. (doi:10.1097/01.MP.0000047306.72278.39)

Renaud S, Loukinov D, Bosman FT, Lobanenkov V \& Benhattar J 2005 CTCF binds the proximal exonic region of hTERT and inhibits its

Published by Bioscientifica Ltd 
transcription. Nucleic Acids Research 33 6850-6860. (doi:10.1093/nar/ gki989)

Saeboe-Larssen S, Fossberg E \& Gaudernack G 2006 Characterization of novel alternative splicing sites in human telomerase reverse transcriptase (hTERT): analysis of expression and mutual correlation in mRNA isoforms from normal and tumour tissues. BMC Molecular Biology 7 26. (doi:10.1186/1471-2199-7-26)

Saji M, Xydas S, Westra WH, Liang CK, Clark DP, Udelsman R, Umbricht CB, Sukumar S \& Zeiger MA 1999 Human telomerase reverse transcriptase (hTERT) gene expression in thyroid neoplasms. Clinical Cancer Research 5 1483-1489.

Santos JH, Meyer JN, Skorvaga M, Annab LA \& Van Houten B 2004 Mitochondrial hTERT exacerbates free-radical-mediated mtDNA damage. Aging Cell 3 399-411. (doi:10.1111/j.1474-9728. 2004.00124.x)

Santos JH, Meyer JN \& Van Houten B 2006 Mitochondrial localization of telomerase as a determinant for hydrogen peroxide-induced mitochondrial DNA damage and apoptosis. Human Molecular Genetics 15 1757-1768. (doi:10.1093/hmg/ddl098)

Sarin KY, Cheung P, Gilison D, Lee E, Tennen RI, Wang E, Artandi MK, Oro AE \& Artandi SE 2005 Conditional telomerase induction causes proliferation of hair follicle stem cells. Nature 436 1048-1052. (doi:10.1038/nature03836)

Scott GA, Laughlin TS \& Rothberg PG 2013 Mutations of the TERT promoter are common in basal cell carcinoma and squamous cell carcinoma. Modern Pathology 27 516-523. (doi:10.1038/ modpathol.2013.167)

Shay JW \& Bacchetti S 1997 A survey of telomerase activity in human cancer. European Journal of Cancer 33 787-791. (doi:10.1016/S09598049(97)00062-2)

Shkreli M, Sarin KY, Pech MF, Papeta N, Chang W, Brockman SA, Cheung P, Lee E, Kuhnert F, Olson JL, et al. 2012 Reversible cell-cycle entry in adult kidney podocytes through regulated control of telomerase and Wnt signaling. Nature Medicine 18 111-119. (doi:10.1038/nm.2550)

Simon M, Hosen I, Gousias K, Rachakonda S, Heidenreich B, Gessi M, Schramm J, Hemminki K, Waha A \& Kumar R 2015 TERT promoter mutations: a novel independent prognostic factor in primary glioblastomas. Neuro-Oncology 17 45-52. (doi:10.1093/neuonc/ nou158)

Singhapol C, Pal D, Czapiewski R, Porika M, Nelson G \& Saretzki GC 2013 Mitochondrial telomerase protects cancer cells from nuclear DNA damage and apoptosis. PLOS ONE 8 e52989. (doi:10.1371/ journal.pone.0052989)

Smith LL, Coller HA \& Roberts JM 2003 Telomerase modulates expression of growth-controlling genes and enhances cell proliferation. Nature Cell Biology 5 474-479. (doi:10.1038/ncb985)

Song YS, Lim JA, Choi H, Won JK, Moon JH, Cho SW, Lee KE, Park YJ, Yi KH, Park do J, et al. 2016 Prognostic effects of TERT promoter mutations are enhanced by coexistence with BRAF or RAS mutations and strengthen the risk prediction by the ATA or TNM staging system in differentiated thyroid cancer patients. Cancer $\mathbf{1 2 2}$ 1370-1379. (doi:10.1002/cncr.29934)

Stern JL, Theodorescu D, Vogelstein B, Papadopoulos N \& Cech TR 2015 Mutation of the TERT promoter, switch to active chromatin, and monoallelic TERT expression in multiple cancers. Genes and Development 29 2219-2224. (doi:10.1101/ $\operatorname{gad} .269498 .115)$

Stewart SA, Hahn WC, O'Connor BF, Banner EN, Lundberg AS, Modha P, Mizuno H, Brooks MW, Fleming M, Zimonjic DB, et al. 2002 Telomerase contributes to tumorigenesis by a telomere lengthindependent mechanism. PNAS 99 12606-12611. (doi:10.1073/ pnas.182407599)

Strong MA, Vidal-Cardenas SL, Karim B, Yu H, Guo N \& Greider CW 2011 Phenotypes in mTERT(+)/(-) and mTERT(-)/(-) mice are due to short telomeres, not telomere-independent functions of telomerase reverse transcriptase. Molecular and Cellular Biology 31 2369-2379. (doi:10.1128/MCB.05312-11)

Szostak JW \& Blackburn EH 1982 Cloning yeast telomeres on linear plasmid vectors. Cell 29 245-255. (doi:10.1016/00928674(82)90109-X)

Takakura M, Kyo S, Kanaya T, Hirano H, Takeda J, Yutsudo M \& Inoue M 1999 Cloning of human telomerase catalytic subunit (hTERT) gene promoter and identification of proximal core promoter sequences essential for transcriptional activation in immortalized and cancer cells. Cancer Research 59 551-557.

Takano T, Ito Y, Matsuzuka F, Miya A, Kobayashi K, Yoshida H \& Miyauchi A 2007 Quantitative measurement of telomerase reverse transcriptase, thyroglobulin and thyroid transcription factor 1 mRNAs in anaplastic thyroid carcinoma tissues and cell lines. Oncology Reports 18 715-720. (doi:10.3892/or.18.3.715)

Tang B, Xie R, Qin Y, Xiao YF, Yong X, Zheng L, Dong H \& Yang SM 2016 Human telomerase reverse transcriptase (hTERT) promotes gastric cancer invasion through cooperating with c-Myc to upregulate heparanase expression. Oncotarget 7 11364-11379. (doi:10.18632/oncotarget.6575)

Vallarelli AF, Rachakonda PS, Andre J, Heidenreich B, Riffaud L, Bensussan A, Kumar R \& Dumaz N 2016 TERT promoter mutations in melanoma render TERT expression dependent on MAPK pathway activation. Oncotarget 7 53127-53136. (doi:10.18632/ oncotarget.10634)

Vinagre J, Almeida A, Populo H, Batista R, Lyra J, Pinto V, Coelho R, Celestino R, Prazeres H, Lima L, et al. 2013 Frequency of TERT promoter mutations in human cancers. Nature Communications 4 2185. (doi:10.1038/ncomms3185)

Wang N, Liu T, Sofiadis A, Juhlin CC, Zedenius J, Hoog A, Larsson C \& Xu D 2014 TERT promoter mutation as an early genetic event activating telomerase in follicular thyroid adenoma (FTA) and atypical FTA. Cancer 120 2965-2979. (doi:10.1002/ cncr.28800)

Wege H, Heim D, Lutgehetmann M, Dierlamm J, Lohse AW \& Brummendorf TH 2011 Forced activation of beta-catenin signaling supports the transformation of hTERT-immortalized human fetal hepatocytes. Molecular Cancer Research 9 1222-1231. (doi:10.1158/1541-7786.MCR-10-0474)

Weinrich SL, Pruzan R, Ma L, Ouellette M, Tesmer VM, Holt SE, Bodnar AG, Lichtsteiner S, Kim NW, Trager JB, et al. 1997 Reconstitution of human telomerase with the template RNA component hTR and the catalytic protein subunit hTRT. Nature Genetics 17 498-502. (doi:10.1038/ng1297-498)

Wellinger RJ \& Sen D 1997 The DNA structures at the ends of eukaryotic chromosomes. European Journal of Cancer 33 735-749. (doi:10.1016/ S0959-8049(97)00067-1)

Weng NP, Hathcock KS \& Hodes RJ 1998 Regulation of telomere length and telomerase in T and B cells: a mechanism for maintaining replicative potential. Immunity 9 151-157. (doi:10.1016/S10747613(00)80597-X)

Wick M, Zubov D \& Hagen G 1999 Genomic organization and promoter characterization of the gene encoding the human telomerase reverse transcriptase (hTERT). Gene 232 97-106. (doi:10.1016/S03781119(99)00108-0)

Wright WE, Piatyszek MA, Rainey WE, Byrd W \& Shay JW 1996 Telomerase activity in human germline and embryonic tissues and cells. Developmental Genetics 18 173-179. (doi:10.1002/(SICI)15206408(1996)18:2<173::AID-DVG10>3.0.CO;2-3)

Wu KJ, Grandori C, Amacker M, Simon-Vermot N, Polack A, Lingner J \& Dalla-Favera R 1999 Direct activation of TERT transcription by c-MYC. Nature Genetics 21 220-224. (doi:10.1038/6010)

Wu RC, Ayhan A, Maeda D, Kim KR, Clarke BA, Shaw P, Chui MH, Rosen B, Shih Ie M \& Wang TL 2014 Frequent somatic mutations of the telomerase reverse transcriptase promoter in ovarian clear cell carcinoma but not in other major types of gynaecological 
malignancy. Journal of Pathology 232 473-481. (doi:10.1002/ path.4315)

Xi L, Schmidt JC, Zaug AJ, Ascarrunz DR \& Cech TR 2015 A novel two-step genome editing strategy with CRISPR-Cas9 provides new insights into telomerase action and TERT gene expression. Genome Biology 16 231. (doi:10.1186/s13059-015-0791-1)

Xing M, Liu R, Liu X, Murugan AK, Zhu G, Zeiger MA, Pai S \& Bishop J 2014 BRAF V600E and TERT promoter mutations cooperatively identify the most aggressive papillary thyroid cancer with highest recurrence. Journal of Clinical Oncology 32 2718-2726. (doi:10.1200/ JCO.2014.55.5094)

Yi X, Tesmer VM, Savre-Train I, Shay JW \& Wright WE 1999 Both transcriptional and posttranscriptional mechanisms regulate human telomerase template RNA levels. Molecular and Cellular Biology 19 3989-3997. (doi:10.1128/MCB.19.6.3989)

Yin L, Hubbard AK \& Giardina C 2000 NF-kappa B regulates transcription of the mouse telomerase catalytic subunit. Journal of Biological Chemistry 275 36671-36675. (doi:10.1074/jbc. M007378200)

Young JI, Sedivy JM \& Smith JR 2003 Telomerase expression in normal human fibroblasts stabilizes DNA 5-methylcytosine transferase I.
Journal of Biological Chemistry 278 19904-19908. (doi:10.1074/jbc. M301685200)

Yuan Y, Qi C, Maling G, Xiang W, Yanhui L, Ruofei L, Yunhe M, Jiewen L \& Qing M 2016 TERT mutation in glioma: Frequency, prognosis and risk. Journal of Clinical Neuroscience 26 57-62. (doi:10.1016/j.jocn.2015.05.066)

Zhang Y, Toh L, Lau P \& Wang X 2012 Human telomerase reverse transcriptase (hTERT) is a novel target of the Wnt/beta-catenin pathway in human cancer. Journal of Biological Chemistry 287 32494-32511. (doi:10.1074/jbc.M112.368282)

Zhou L, Zheng D, Wang M \& Cong YS 2009 Telomerase reverse transcriptase activates the expression of vascular endothelial growth factor independent of telomerase activity. Biochemical and Biophysical Research Communications 386 739-743. (doi:10.1016/j.bbrc.2009.06.116)

Zhou J, Mao B, Zhou Q, Ding D, Wang M, Guo P, Gao Y, Shay JW, Yuan Z \& Cong YS 2014 Endoplasmic reticulum stress activates telomerase. Aging Cell 13 197-200. (doi:10.1111/acel.12161)

Zuo QP, Liu SK, Li ZJ, Li B, Zhou YL, Guo R \& Huang LH 2011 NF-kappaB p65 modulates the telomerase reverse transcriptase in the HepG(2) hepatoma cell line. European Journal of Pharmacology $\mathbf{6 7 2}$ 113-120. (doi:10.1016/j.ejphar.2011.09.187)

Received in final form 15 December 2016 Accepted 5 January 2017

Accepted Preprint published online 5 January 2017 http://jme.endocrinology-journals.org DOI: 10.1530/JME-16-0195
C) 2017 Society for Endocrinology Printed in Great Britain
Published by Bioscientifica Ltd. 